\title{
Educational Activities of Agritourism Farms in Poland
}

\author{
Marzena KACPRZAK ${ }^{1}$, Katarzyna GRALAK ${ }^{1}$, Izabela WIELEWSKA ${ }^{2}$ \\ ${ }^{1}$ Warsaw University of Life Sciences, Warsaw, Poland \\ \{marzena_kacprzak, katarzyna_gralak\}@sggw.pl \\ ${ }^{2}$ UTP University of Science and Technology in Bydgoszcz, Bydgoszcz, Poland \\ izabel2000@wp.pl
}

\begin{abstract}
The paper presents the educational offer of agritourism farms in Poland. The research was carried out at the Department of European Policy and Marketing of the Warsaw University of Life Sciences (SGGW) in 2017 using the diagnostic sampling method and a questionnaire technique. The educational activity of the agritourism farms was evaluated, taking into account such factors as: economic and structural conditions, natural and cultural qualities, tourism development, thematic profiles of farms: education, production, service or care. At present, we have unlimited access to a lot of information through the development of new technologies. Certain knowledge is therefore required to understand educational processes, relations with the environment and setting new requirements for agritourism farms that wish to expand their activities in the field of educational challenges. The surveyed agritourism farms offer their customers a very wide and diversified range of educational profiles. The most frequently offered activity profiles of farms include: sport and recreation, arts and crafts, agricultural and farming activities as well as traditional food.
\end{abstract}

Keywords: Agritourism, Agritourism Farms, Educational Offer.

\section{Introduction}

Currently, there are significant changes, both social, political and economic in Poland. These apply to many branches of the country's economy. New situations and challenges have also affected the Polish countryside. For many families living in the countryside, new opportunities emerged for seeking additional sources of income, self-employment, and thus new jobs, which would improve the financial situation of not only farmers, but residents of entire villages or boroughs [15].

When providing services for tourists, there is a great emphasis on creativity, innovation as well as education and development of human capital. This will allow to achieve economic and social benefits from running agritourism and working for the benefit of the local community $[1,8,9]$.

In many European countries, educational activities are carried out using farms. In France, in 740 educational farms, the range of organized activities is determined by the 
farmer's family, who prepare such activities and carry them out together with youths or children [3]. In 2010, there were 19,973 farms in Italy offering various services to tourists. Agritourism is concentrated in two regions: Trentino and Tuscany. South Tyrol is a region which intensively develops agritourism activity. The offer of the farms is very diverse, ranging from small family farms to luxury facilities, offering services of the highest quality, and in particular [12]:

- owners who live in the city, even at a large distance, own a farm or several independent houses, which have been transformed into independent apartments, each of them with a kitchenette, and a swimming pool and other facilities complement the offer. Relations with guests are minimal and the property is managed by an administrator;

- owners of large mansions, even a castle, offering luxurious rooms, elegantly furnished common spaces (reading room, piano, etc.); there is an on-site swimming pool, gym, spa, horse riding. Highly qualified staff manages the entire company, and the presence of the owner is occasional;

- members of former production cooperatives, in which available buildings have been transformed into rooms and apartments, catering facilities and restaurants. The members of the cooperative participate in the implementation of various tasks, from management to reception, through cooking, restaurant service, etc.,

- owners of medium and large farms, offering rooms and apartments, common spaces, a small swimming pool, a restaurant; most of the work is done by the family members;

- small farmers, offering modestly furnished rooms and apartments, with a small dining room where the guests and the family sometimes eat together. The external equipment is minimal;

- educational farms, designed for urban children, offer themes related to nature, agriculture, food and nutrition, and are usually managed by cooperatives or farmers;

- organic farms, usually managed by cooperatives or small farmers.

The aim of the article is to present the thematic diversity of selected agritourism farms for educational services provided.

\section{New Functions of Farms}

Agritourism fulfils many important functions both for residents of urban and rural population $[7,10]$. Those functions should be understood as tasks and duties to be performed and results arising from their implementation. In their paper entitled Agritourism, M. Sznajder and L. Przezbórska distinguish the following functions: income, employment, use of free housing resources, activation of rural areas, conservation of natural resources as well as leisure, recreational and educational functions of the urban population [14]. In the study Rural tourism and education various levels, different dimensions, the authors M. Marks, A. Jaszczak and E. Marks divided agritourism functions in relation to tourists and farm owners [13]: Educational functions of agritourism in relation to tourists are as follows: 
- getting to know the lifestyle and work of farmers,

- the opportunity to participate in the production and acquisition of food,

- participating in the preparation and consumption of regional dishes,

- learning about the cultural heritage of the Polish countryside,

- learning about local customs, customs and folk traditions,

- crafts and handicrafts,

- the opportunity to shape appropriate attitudes towards nature and landscape protection.

Educational functions of agritourism in relation to farm owners include the following areas:

- assimilation of positive role models - the cultural aspect and an increase in the standard of living,

- broadening social contacts,

- the possibility of social and professional promotion,

- new perspectives for the rural population,

- integration of the rural environment,

- increase in moral tolerance.

Contemporary rural areas are becoming more and more attractive tourist destinations and are used for relaxation and recreation. Trips to the countryside for leisure purposes have become a way to spend holidays or long weekends. The country is a very attractive destination due to the natural, clean environment, beautiful landscapes, the opportunity to learn about farms and participate in the life of the hosts, healthy, natural food, learning about farm animals, etc. It is especially popular for farms with a small area (up to $10 \mathrm{ha}$ ) with a multidirectional production and breeding. Such farms account for $66 \%$ of all rural accommodation facilities participating in the categorization system [6].

In many educational programs implemented on farms, attention is also paid to the cultural aspects of the regions. In this case, the travellers' interests focus on the rich past of residents or areas, preserved and reflected in monuments, historical surroundings, traditional architecture and folk handicrafts [11].

Also, many agritourism farms organize culinary workshops, during which tourists participate in the process of preparing healthy, regional meals, and also learn about regional cuisine "from the inside". In culinary tourism, the local and ecological origin of food products is important, e.g. vegetables and fruits from own organic farming, meats smoked in own smokehouses according to regional regulations, etc. [4].

Through their offer, educational farms promote the countryside, its natural and cultural values. An innovation in the subject of educational tourism is the emergence of Educational Homesteads [2], whose task is to promote folk traditions and culture, disseminate the idea of education in an agricultural household and arouse the curiosity of getting to know the farmer's work and rural life.

To sum up - the functions of agritourism are very important for both tourists and guests and for farm owners. Some of these functions overlap or complement each other. It is difficult to identify which are more important and which are less important. Each has a different but very important role. 


\section{Methodology and Goal of the Paper}

The aim of the article is to present the thematic diversity of selected agritourism farms for educational services provided.

The research was carried out at the Department of European Policy and Marketing of the Warsaw University of Life Sciences (SGGW) [5] in 2017 using the diagnostic sampling method and a questionnaire technique. The research tool was a questionnaire, which consisted of 19 questions regarding the offer of agritourism farms, educational profiles, ideas for expanding the educational offer and the educational programs themselves.

120 questionnaires for randomly selected owners of agritourism farms were sent via e-mail. 57 correctly completed surveys were received, including: 5 surveys from Mazowieckie Province and 4 surveys from agritourism farms from Warmińskomazurskie, Świętokrzyskie, Podkarpackie, Pomerania, Lubelskie, Opolskie, Kujawskopomorskie, Śląskie, Lubuskie, Wielkopolskie, Małopolskie, Lower Silesia and West Pomerania Provinces. The collected research material was subjected to statistical analysis. The results obtained from the research were described and presented in the form of tables and graphs.

\section{Educational Household in the Light of the Research Results}

The respondents were asked to indicate how they understood the term "educational farm". The research conducted showed that the respondents mostly associate this concept with the educational offer that such farms propose. The majority (14\%) of respondents think that it is an agricultural farm in which the guests actively participate in agricultural work. Also, the same number of respondents recognize an educational household as one conducting educational classes. According to the respondents, the relaxation at the farm and staying in an ecological, clean environment (6 responses each) are also assigned to the idea of educational farm. In the opinion of the respondents, an educational farm is also one that receives guests, an agricultural farm that receives guests and offers accommodation as well as a farm whose main purpose is education ( 5 responses each), a farm with traditional regional cuisine and a farm with livestock (4 responses each).

According to $5.3 \%$ of respondents, the term "educational farm" is strictly defined by law. Two people associated such a farm with the organization of "Green Schools", and one as a farm offering leisure away from the city (see Tab. 1).

The respondents were asked if they had an educational offer on their agritourism farm. The vast majority ( $88 \%$ ) of agritourism farms have an educational offer targeted at customers, and only $12 \%$ do not have such offers. 
Table 1. Educational farm according to the respondents.

\begin{tabular}{lll}
\hline The respondents' answers & $\begin{array}{l}\text { Number of } \\
\text { answers }\end{array}$ & $\%$ \\
\hline Farm household receiving visitors & 5 & 8.8 \\
Farm household receiving visitors with accommodation & 5 & 8.8 \\
What the law says & 3 & 5.3 \\
Farm household in which visitors actively participate in agricultural & 8 & 14.0 \\
work & 6 & \\
Relaxation at the farm & 6 & 10.5 \\
Staying in an ecological, clean environment & 4 & 7.5 \\
A farm with traditional regional cuisine & 8 & 14.0 \\
A farm offering educational activities & 2 & 3.5 \\
Organizing "Green Schools" & 4 & 7.0 \\
A farm with livestock & 5 & 8.8 \\
A farm whose main purpose is education & 1 & 1.8 \\
A farm offering leisure away from the city & & \\
\hline
\end{tabular}

The respondents were asked to indicate which customers (recipients) the agritourism farm is aimed at, and thus - who is the offer addressed to? The research conducted showed that the most offers are targeted at families with children. Farms with a comprehensive business profile came in second (see Fig. 1).

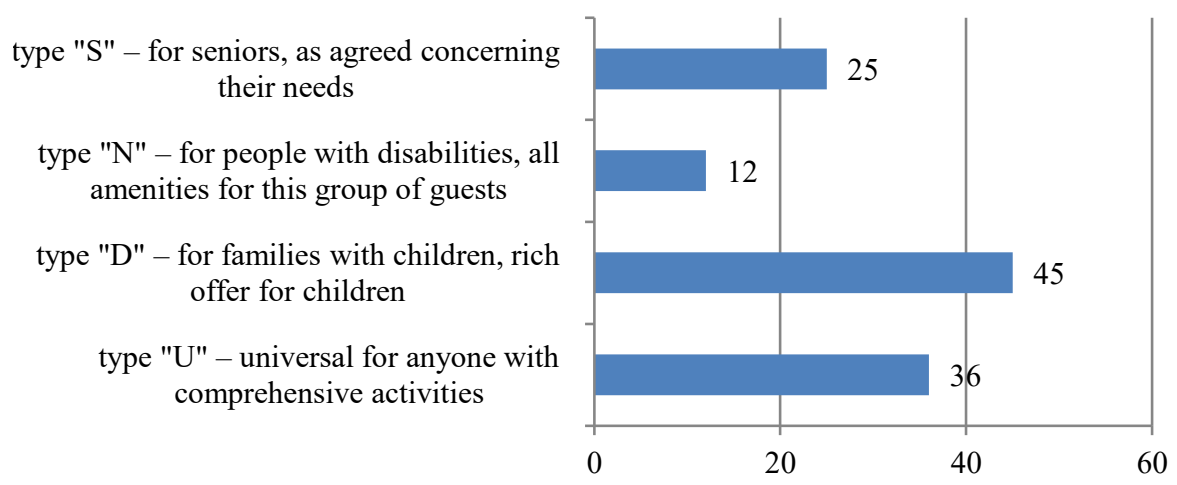

Fig. 1. Customers of agritourism farms. *more than one answer could be selected.

With consideration to the preparation of a good educational offer, the respondents were asked to indicate which educational profiles are offered to guests in their agritourism farms. This was a multiple-choice question (see Fig. 2). 


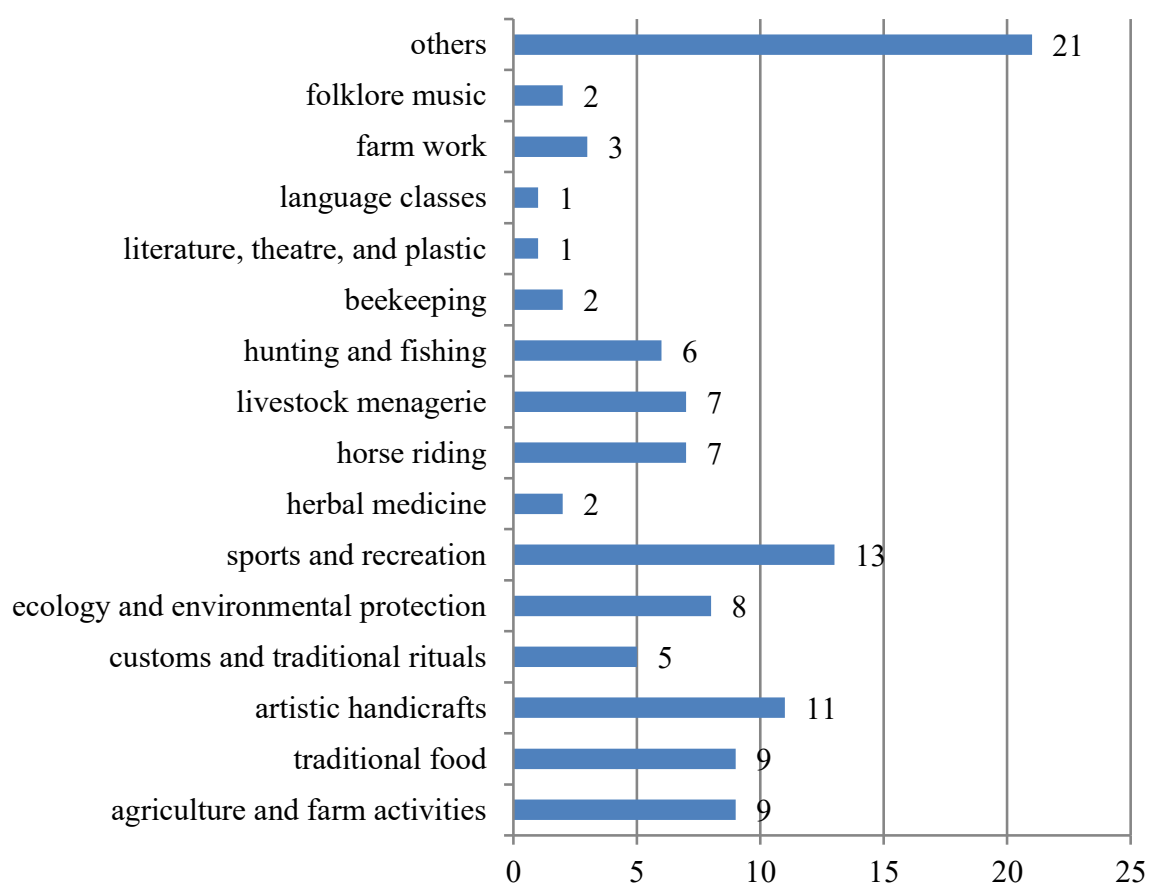

Fig. 2. Educational profiles of farms offered to guests. *more than one answer could be selected.

Among the 15 educational profiles proposed, the most frequently mentioned profile was sports and recreation. Artistic handicrafts, agriculture and farm activities as well as traditional food came next in the list. The least popular educational offers among the surveyed agritourism farms were literature, theatre, art and language classes. The "others" option was chosen by 21 respondents.

The respondents were also asked about the promotion of the farm. The purpose of the question about the promotion of the farm was to get information on whether and how hosts promote their farms and what means they use for this purpose. The results are shown in Figure 3.

53 out of 57 respondents have their own website. The potential of the Internet is a versatile tool of promotion and communication, used not only in educational activities. Agritourism farms use the Internet to build their own image. 45 out of 57 surveyed farms use promotion in the form of leaflets distribution. The least popular form of promoting the farm is advertising in the media (radio and what is certainly associated with very high costs: placing advertisements in thematic newspapers and the press). 


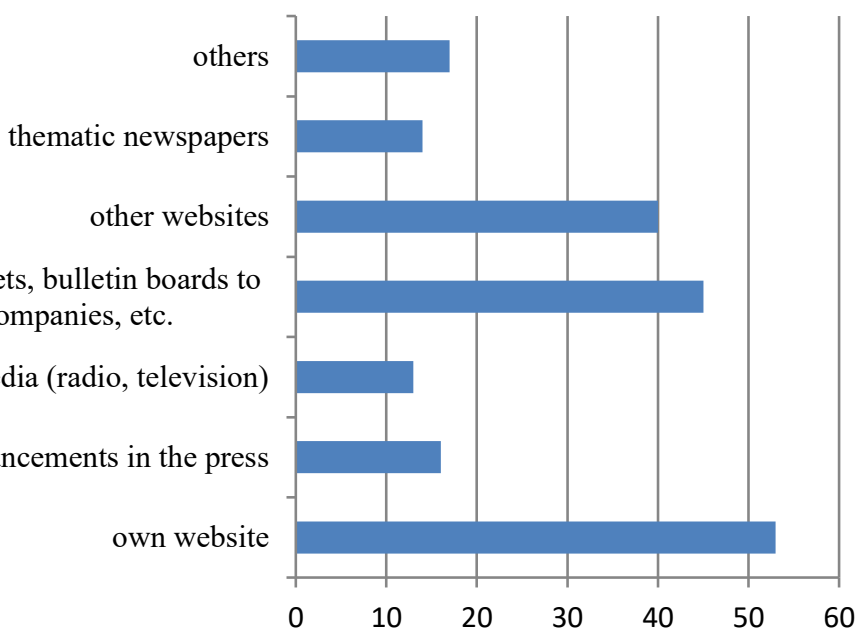

Fig. 3. Promotion of the farm.

The educational function of an agritourism farm should include knowledge about the development of agricultural production, new solutions in the field of animal husbandry or new species and strains of plants. Therefore, the respondents were asked to indicate how they developed their knowledge in this area. The respondents had only one choice of answer in the field of broadening their knowledge of agritourism (see Fig. 4).

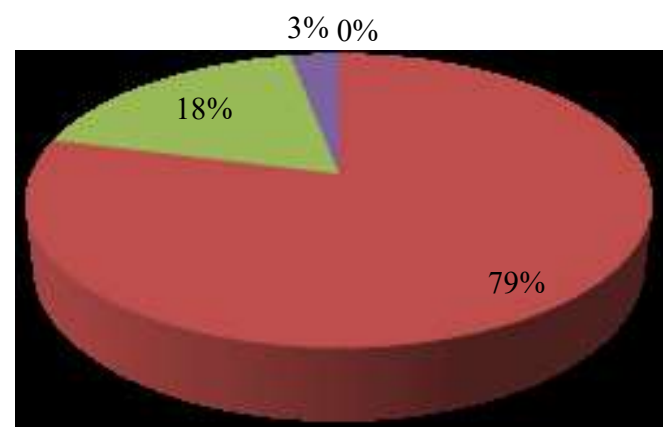

I do not take any action in this direction

- I take part in trainings, courses organized by the borough, etc.

I pursue education on my own and at my own

expense

other

Fig. 4. Knowledge in the field of agritourism.

The vast majority of the surveyed take part in courses and training organized by the borough councils and Agricultural Advisory Centres. $18 \%$ of the respondents pursue education on their own and at their own expense. 3\% of respondents broaden their knowledge in another way. There are no people among the respondents who do not take any steps towards expanding knowledge in the field of agritourism. 
All farmers participating in the study take their ideas for expanding the educational offer from the opinions and suggestions of guests. As many as 53 of the surveyed farmers draw ideas for extending the educational offer from the Internet. 47 respondents use their own ideas and those of their family members; another 48 farms use observation of the activities of other farms. The knowledge from training is used by 45 respondents. The "others" option was selected by 12 respondents (see Fig. 5).

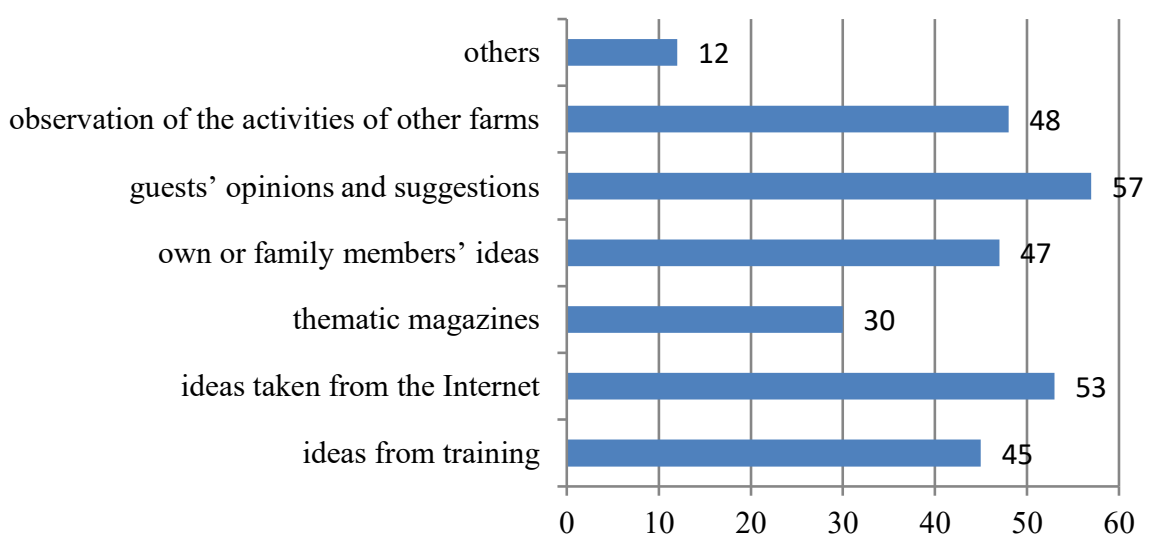

Fig. 5. Ideas for expanding the educational offer.

$81 \%$ of agritourism farms have a special programme for the youngest guests. Ordered thematic blocks addressed to the youngest are presented in Table 2 .

Data analysis shows that the educational offer for children is relatively diverse. Most frequently, there are classes related to the process of baking bread (10 farms offer such an educational program). The subject of beekeeping (6 farms) and the 'seasons of the year on an agritourism farm' ( 6 farms) are equally popular.

Table 2. Educational programmes targeted at the youngest.

\begin{tabular}{ll}
\hline Educational programme & $\begin{array}{l}\text { Number of households } \\
\text { undertaking such programmes }\end{array}$ \\
\hline "From grain to bread" & 10 \\
"Tissue paper world" - products from tissue paper & 3 \\
"The horse in the household" & 4 \\
Lesson about milk & 6 \\
Lesson about cereals and grain & 4 \\
Gluing and clay pottery & 4 \\
Christmas decorations from salt mass & 3 \\
Honey - how it is made; bees, apiaries & 6 \\
Agriculture and farming activities & 4 \\
4 seasons at the farming household & 6 \\
Learning about farming livestock & 6 \\
\hline
\end{tabular}


The lessons about milk and farm animals are also offered by 6 farms. The lessons about grain, gluing and clay pottery products as well as agriculture and farm classes are offered by 4 agritourism farms).

\section{Conclusion}

The aim of this paper was to examine randomly selected agritourism farms in terms of the educational offer that they have and the thematic variety of various educational offers. 57 agritourism farms from all over the country participated in the study. Research has shown that $88 \%$ of surveyed agritourism farms have some kind of educational offer addressed to their customers. Only 45 out of the 57 surveyed farms direct their offer to families with children and specialize in this.

The surveyed agritourism farms offer their customers a very wide and diversified range of educational profiles. The most frequently offered activity profile of farms are: sport and recreation, arts and crafts, agriculture and farm activities as well as traditional cuisine. The researched farms try to match their educational profiles to individual age groups of the customers. Another thematic scope is offered to the youngest and yet another to high school students and adults. As many as $81 \%$ of the households participating in the study have a special programme addressed to the youngest age group. Most often, these are thematic blocks closely related to the farmers' work, e.g.: the process of baking bread, the horse on the farm, milk lesson, cereals, farm animals, 4 seasons in a farm yard, honey and beekeeping.

\section{References}

1. Balińska-Grzelak, A.: The Role of Social Participation in the Stimulation of the Development of Tourism. Scientific Papers of Szczecin University, Economic Problems of Tourism, Issue No. 738, 14-17 (2012).

2. Bogusz, M., Kania, J.: Educational Homesteads as Examples of Innovative Entrepreneurship. In: Jęczmyk, A., Uglis, J., Maćkowiak, M.: Rural Tourism. Economic and Marketing Issues, vol. 1, published by Wieś Jutra Publishing House, Poznań (2016).

3. Dziasek-Kmita, E.: Wprowadzenie do zagadnień edukacji w gospodarstwie rolnym, Wydawnictwo Centrum Doradztwa Rolniczego w Brwinowie, Oddział w Krakowie, Kraków (2011).

4. Gutkowska, K., Gajowa, K., Piekut, M.: Possibilities for the Development of Culinary Tourism in Poland, Progress in Food Processing Technology, Issue No 2 (2015).

5. Grządziela, P.: Educational Activity of Agritourism Households in Poland, A Master's Thesis written at the Department of Marketing and European Politics, SGGW, Warsaw (2017).

6. http://ksow.pl/uploads/tx_library/files/01_Wprowadzenie_do_zagadnień_edukacji_w_gospo darstwie rolnym.pdf, last accessed 2017/07/07.

7. Idziak, W. et al: Rural Tourism and Agritourism in the Financial Perspective 2014-2020, commisioned by the Ministry of Agriculture and Rural Development, Warsaw 2015.

8. Kacprzak, M.: Agroturystyka jako szansa rozwoju turystyki rodzinnej-przykład Małopolski. In: Iwan, B. (ed.) Kultura i przyroda w turystyce górskiej, Wyd. WSTiJO w Warszawie, Warszawa (2017). 
9. Kacprzak, M., Kró,1 A., Wielewska, I.: Human Capital on the European Labour Market. In: Problems of World Agriculture, 17 (4), 143-150 (2017). DOI: 10.22630/PRS.2017.17.4.90.

10. Kryński, Z., Kusz, D., Augustyńska-Preisnar, A.: Motywy podejmowania działalności agroturystycznej. In: Turystyka wiejska a rozwój I współpraca regionów, Prace NaukowoDydaktyczne PWSZZ w Krośnie, Handbook \#15, Krosno (2005).

11. Metelka, Ch. J.: The Dictionary of Hospitality, Travel and Tourism, Delmar Publishers Ins., Merton house travel and tourism published, Albany - New Jork, USA (1990).

12. Santucci, F. M.: Agritourism for Rural Development in Italy, Evolution, Situation and Perspectives, British Journal of Economics, Management \& Trade, 3(3) (2013).

13. Sikora, J. (ed.): Turystyka wiejska a edukacja, różne poziomy, różne wymiary, Wydawnictwo Akademii Rolniczej im. Augusta Cieszkowskiego w Poznaniu, pp. 40-45, Poznań (2007).

14. Sznajder, M., Przezbórska, L.: Agroturystyka, PWE, Warszawa (2006).

15. Wielewska, I., Kacprzak, M., Król, A., Siedlecka, A.: Human Capital in the Aspect of Raising Innovativeness in Rural Areas. In: International Scientific Days 2018. "Towards Productive, Sustainable and Resilient Global Agriculture and Food Systems." Conference Proceedings, pp. 1810-1823, Nitra (2018). 